\title{
Reading Habits Amongst University Undergraduates: Implications for Academic Performance
}

\author{
Labo-Popoola Serifat Olubunmi \\ Department of Languages and Literary Studies \\ Faculty of Arts, Adeleke University, Ede, Nigeria.
}

Tel: 234-080-3397-7411_E-mail: shareefah717@yahoo.co.uk

\begin{abstract}
Received: May 7, 2017 Accepted: May 29, 2017 Published: June 19, 2017
doi:10.5296/ijld.v8i2.13102 URL: https://doi.org/10.5296/ijld.v8i2.13102
\end{abstract}

\begin{abstract}
Human beings transmit knowledge from one generation to another through many ways/skills. This is why the human being is different from other creatures. One of the many tools used by humans is reading. Reading is, no doubt, a complex but very important skill needed by everyone who wishes to succeed in life. The ultimate goal of reading is to be able to understand/comprehend written material, evaluate it, and use the material for one's need. Comprehension, therefore, is required of the material read. Reading has a lot to do in one's life as it is the foundation of enjoyment in life; it is equally a valuable key needed to carry out certain skills. For every student, reading takes a large chunk of time in academic pursuit if he/she plans to succeed. A student who finds it difficult to engage in serious reading is not likely to do well in his/her studies. A student must be able to read fluently to gain comprehension, thereby improving in his/her studies. Today, casual observation of students have shown that students do not want to engage in reading, let alone in serious reading, though when confronted with examinations, they are compelled to read. The age of reading novels, science fiction, etc. seems gone. If this is the situation, how do they fare in their academics? This study is therefore conducted to investigate/assess students' reading habits/culture and how this impacted on their level of intelligence or academics. Four research questions guided the conduct of the research work. A questionnaire was used for data collection from university undergraduates. The data obtained was analyzed quantitatively using the Statistical Package for Social Science. The study reported a high perception of reading among the university undergraduates. The respondents agreed with the proposition that there exists a relationship between reading and their academic performance. Though there is a decline in reading, this can be addressed by inculcating reading as a subject into the academic curriculum at the tertiary level. Other means are establishing reading clubs/centres/clinics in and around the higher
\end{abstract}


institutions. The paper therefore recommends that teachers/ lecturers should be equipped with trainings that will make them teach reading effectively. The General Studies Programme of all Universities should incorporate reading as a course into the curriculum of the Programme.

Keywords: Reading habits, undergraduates, academic performance

\section{Introduction}

For success in any life endeavour, the language skills (listening, speaking, reading and writing) cannot be wished away. Of all the language skills, the reading skill is very paramount in comprehension and success for student. Rubin (2002) as quoted by Aina, Ogungbemi, Adigun, Akesode and Ogundipe (2011) described reading as a total integrative process that starts with the reader and includes the affective, perceptual and cognitive domains. Through reading, therefore, an individual gets developed in the three domains of education. Reading can therefore develop the individual affectively, cognitively as well as his psychomotor traits. To succeed in school, and invariably in life, means to be competent in reading.

Reading enables one to be abreast of information as information is life. The ability to read in life is critical to success in life. It is therefore a skill that has to be inculcated in an individual right from childhood. It should form part of the child's social interaction. Aina, et al (2011) observed that reading is a skill that must be nurtured from a child's earliest years. However, children need support to reach their full potential as readers, even after knowing how to read. Reading, as a skill, should not be associated with school work alone. It should be seen as the foundation of much enjoyment in life. Tracy (2008) noted that reading is the only form of entertainment that is also an essential life skill.

Acquiring good or efficient reading skill has a long term effect on school performance, as poor reading ability can make a child develop poor attitude towards school. Developing poor attitude towards school no doubt affects the child's performance in school which can lead to low self-esteem later in life. Children with poor reading ability or skill are likely to have poor grades in school. According to Robin (2002), children with poor reading habits have a higher chance of anti-social behavior. This may not be so at all times; it has been noted that people with poor reading habits are likely to exhibit anti-social behavior. It is therefore necessary for every child/student to develop a good reading habit for him/her to succeed in school. Studies have shown that there exists a relationship between reading/early literacy and a child's emotional, mental health and social behaviour. Antwi (1985) in a study reported a direct correlation between the degree of seriousness of delinquency and the degree of severity of reading problems. The study revealed that students who struggle with literacy begin to experience failure and related negative effects in interpersonal skills.

Reading means different things to different people; hence people engage in reading for different reasons. To a lot of people, especially students, reading is done mainly to pass examinations and not because of the knowledge to be gained. Some read for pleasure and relaxation while a few are likely to read for self-improvement in life. Aina, et al (2011) reported a study carried out by Henry (2004) who found out that $40 \%$ of adult Nigerians 
never read a non-fiction book after they completed school. The study revealed that an average Nigerian reads less than a book in a year; many Nigerians graduated from the high school with poor reading skills. This is quite disturbing because if graduates have poor reading skills, one can imagine what the situation would be amongst secondary school students or primary school pupils.

There is no doubt that competence in reading is of utmost importance since effective learning of any subject in the curriculum depends on the learners' ability to read and understand. Isiugo-Abanihe (1991), Adegbile (2002), Bashir and Mattaoo (2012) and Palani (2012) all confirmed that achievement in reading influences the understanding of other subjects. Palani (2012) is of the opinion that reading shapes personality and helps in developing proper thinking methods.

It is against this background that this study is conceived, to specifically; investigate the reading habits amongst undergraduates. If graduates of past years have retained poor reading skills, what is the situation today? Though a lot has been done in reading/reading habits, there is need to investigate if, and why, there is a decline in the reading culture of undergraduates; what these undergraduates do with their leisure time; their perception about reading; etc. The study also sought to establish if there exists a relationship between reading and achievement of students.

\subsection{Research Questions}

Four research questions were formulated to guide the research work. These include:

i. What is student's perception of reading?

ii. What are the factors / reasons for the decline in reading among undergraduates?

iii. How can the decline be corrected /addressed?

iv. Is there a relationship between reading and academic performance of undergraduates?

\section{Methodology}

The study employed the descriptive survey research design. A Questionnaire titled "Questionnaire on Reading for Undergraduates" was used in obtaining information from undergraduates. The questionnaire had three sections. Section 1 required the respondents to provide details of their personal background. Section 2 had items on what the respondents do in their leisure time, types of books they read, reasons for a decline in reading among students ( if there is any), etc. The third section requested them to choose the option that best suits their opinion on items relating to the relationship between their reading pattern/habit and their level of academic performance.

Two hundred and twenty copies of the questionnaire were administered randomly to students in four universities in the State of Osun. The samples were chosen irrespective of their level of study, gender or course of study. One hundred and ninety-eight copies were retrieved and this gave a rate of return of $90 \%$. The data from the questionnaires were analyzed 


\section{Macrothink}

International Journal of Learning and Development

ISSN 2164-4063 2018, Vol. 8, No. 2

quantitatively using the Statistical Package for Social Sciences (SPSS). The results of the findings are presented in tables and figures below.

\subsection{Respondents'Background}

Tables $1 \mathrm{a}$ and $1 \mathrm{~b}$ present the respondents' background as regards their age, gender and level of study in school.

Table 1a. Respondents' background: Age and Gender

\begin{tabular}{lllll}
\hline Age Range & Male (\%) & Female (\%) & Total \% & Cumulative \% \\
\hline Below 20 years & 12.9 & 47.7 & 60.6 & 60.6 \\
20 - 25 years & 14 & 20.7 & 34.7 & 95.3 \\
Above 25 years & 2.6 & 2.1 & 4.7 & 100 \\
Total & 29.5 & 70.5 & 100 & \\
\hline
\end{tabular}

Table 1b. Respondents' background: Gender and Level

\begin{tabular}{lllll}
\hline Level & Male (\%) & Female $(\%)$ & Total & Cumulative \% \\
\hline 100 & 11.4 & 51.8 & 63.2 & 63.2 \\
200 & 8.3 & 8.3 & 16.6 & 79.8 \\
300 & 6.7 & 6.2 & 12.9 & 92.7 \\
400 & 3.1 & 3.6 & 6.7 & 99.4 \\
500 & - & 0.5 & 0.5 & 99.9 \\
Total & 29.5 & 70.4 & 99.9 & \\
\hline
\end{tabular}

From the two tables, the study revealed that there seems to be more female undergraduates in the sampled universities than male students. In terms of age, $60.6 \%$ of the respondents are below 20 years of age while only $4.7 \%$ of them are above 25 years in age. Majority of the respondents $(63.2 \%)$ are in their first year while only $7.2 \%$ belong to the final year (400 and 500 levels).

\subsection{Background of the Respondents in Relation to Reading}

In looking at the background of the respondents in relation to reading, certain indicators were considered. These include how the respondents spend their leisure, the books they preferred to read, the genre of books read, the number of hours spend on reading daily and their opinion about reading habit of undergraduates. Tables $2 \mathrm{a}-2 \mathrm{~d}$ present their responses. 


\section{Ml Macrothink}

Table 2a. Spare Time

\begin{tabular}{lccll}
\hline Variable & Frequency & Percent & Valid Percent & $\begin{array}{l}\text { Cumulative } \\
\text { percent }\end{array}$ \\
\hline PLAY COMPUTER & 22 & 11.1 & 11.6 & 11.6 \\
SLEEP & 50 & 25.3 & 26.3 & 37.9 \\
WATCH TELEVISION & 49 & 24.7 & 25.8 & 63.7 \\
READ BOOKS & 69 & 34.8 & 36.3 & 100.0 \\
TOTAL & 190 & 96.0 & 100.0 & \\
MISSING CASES & 8 & 4 & & \\
TOTAL & 198 & 100 & & \\
\hline
\end{tabular}

Source: Fieldwork, 2017.

Table 2b. Books Preferred

\begin{tabular}{lllll}
\hline & Frequency & Percent & Valid Percent & $\begin{array}{l}\text { Cumulative } \\
\text { percent }\end{array}$ \\
\hline FICTION & 67 & 33.8 & 34.0 & 34.0 \\
NON FICTION & 33 & 16.7 & 16.8 & 50.8 \\
BOTH & 97 & 49.0 & 49.2 & 100.0 \\
TOTAL & 197 & 99.5 & 100.0 & \\
MISSING CASES & 1 & .5 & & \\
TOTAL & 198 & 100 & & \\
\hline
\end{tabular}

Source: Fieldwork, 2017.

Table 2c. Genres of Books read

\begin{tabular}{lllll}
\hline Variable & Frequency & Percent & Valid Percent & Cumulative percent \\
THRILLER & 35 & 17.7 & 20.0 & 20.0 \\
CLASSICS & 28 & 14.1 & 16.0 & 36.0 \\
ROMANCE & 47 & 23.7 & 26.9 & 62.9 \\
COMICS & 33 & 16.7 & 18.9 & 81.7 \\
SCIENCE FICTION & 30 & 15.2 & 17.1 & 98.9 \\
OTHERS (if any) & 2 & 1.0 & 1.1 & 100.0 \\
TOTAL & 175 & 88.4 & 100.0 & \\
MISSING CASES & 23 & 11.6 & & \\
TOTAL & 198 & 100.0 & & \\
\hline
\end{tabular}

Source: Fieldwork, 2017. 


\section{Macrothink}

Table 2d. Opinion about Reading Habit

\begin{tabular}{llllll}
\hline & & Frequency & Percent & Valid Percent & Cumulative Percent \\
\hline \multirow{4}{*}{ Valid } & POOR & 54 & 27.3 & 28.4 & 28.4 \\
& GOOD & 106 & 53.5 & 55.8 & 84.2 \\
& EXCELLENT & 30 & 15.2 & 15.8 & 100.0 \\
& Total & 190 & 96.0 & 100.0 & \\
Missing & System & 8 & 4.0 & & \\
\hline Total & & 198 & 100.0 & &
\end{tabular}

Source: Fieldwork 2017

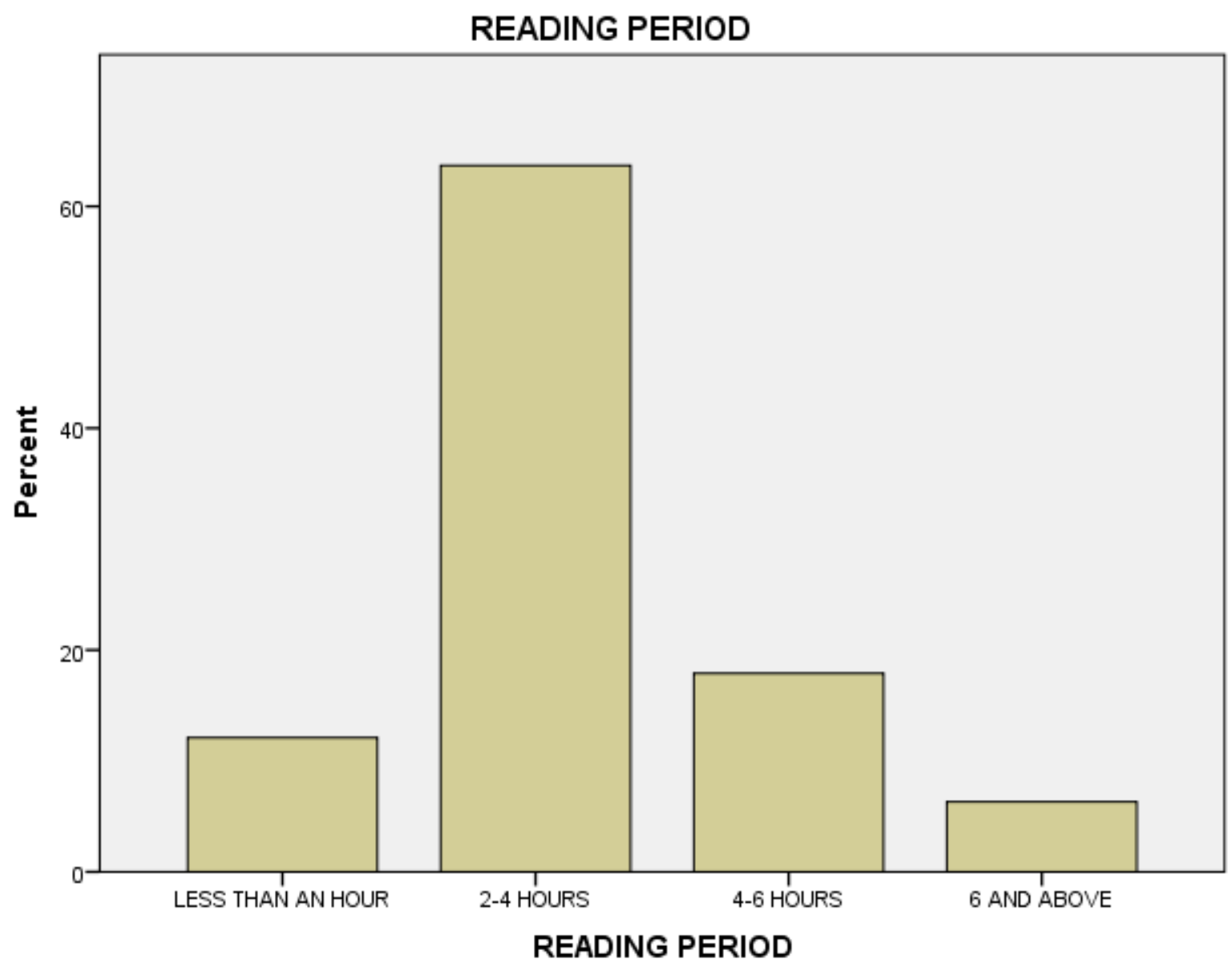

Figure 1. Reading period on daily basis

From Table $2 \mathrm{a}, 36.3 \%$ of the respondents endeavoured to read during their leisure/spare time. Others $(63.7 \%)$ would rather play on computer, watch television or sleep during their leisure. 


\section{Ml Macrothink}

To these students, one can conclude that reading is done only for examination purposes. Tables $2 \mathrm{~b}$ and $2 \mathrm{c}$ present information on the type and genre of books preferred by the respondents. About $49.2 \%$ of the respondents would go for either fiction or non-fiction books while $34 \%$ preferred fiction. Considering the choice of genres, $65.8 \%$ opted for genres such as thrillers $(20 \%)$, romance $(26.9 \%)$ and comics $(18.9 \%)$. The remaining $34.2 \%$ preferred options such as classics (16\%), science fiction (17\%).

Table $2 \mathrm{~d}$ gives the respondents opinion about students' reading habits. Half of the respondents (55.8\%) are of the opinion that the reading habit is good. A quarter of them $(28.4 \%)$ believed that the habit is poor while only $15.8 \%$ opined that the habit is excellent.

Figure 1 showed the number of hours spent on reading on a daily basis. Only about $60 \%$ of the respondents spent between two and four hours on reading daily. Less than $20 \%$ would spend four hours while less than $10 \%$ spent six hours. Spending about 6 hours on reading daily may be a tall order for undergraduates who can be restless as they now engaged in research work. It may not be a too bad idea to spend between 2 and 4 hours on reading daily, if only it is a serious reading. However, it is disheartening to observe that undergraduates would spend less than an hour on reading in a day $(12 \%)$.

Pulling all these variables together, one would want to conclude that the undergraduates engage in both serious and not very serious type of reading. They are likely to engage in serious reading when there are examinations. On a general note, they read more of fiction than non-fiction books.

\section{Presentation of Results}

\subsection{Research Question I: What is the Respondent's Perception of Reading?}

Perception is defined as the power of being aware of something through the senses. The study sought to find out the respondents' perception about reading. Of all the questionnaires administered, $82.8 \%$ of the respondents answered these items. Table 2 presents their perception based on the variables presented to them.

Table 2a. Perception of Reading - All Respondents

\begin{tabular}{lllll}
\hline Variable & Strongly Agree\% & Agree \% & Disagree \% & Strongly Disagree\% \\
\hline Reading is interesting & $\mathbf{5 2 . 9 9}$ & 43.06 & 16.06 & 18.92 \\
Reading is boring & 24.79 & 25.09 & $\mathbf{4 4 . 3 7}$ & 41.89 \\
I find reading very difficult & 22.22 & 31.25 & 39.07 & $\mathbf{3 9 . 1 9}$ \\
& 100 & 100 & 100 & 100 \\
\hline
\end{tabular}

To further analyse the data, the positive response were collated and this gave an average percentage of $97.75 \%(52.99 \%, 44.37 \%$ and $39.07 \%)$ while the negative responses gave an 


\section{Macrothink}

International Journal of Learning and Development

ISSN 2164-4063 2018, Vol. 8, No. 2

average of $24.98 \%$. This implies that majority of the respondents have a very high perception of reading. This finding does not corroborate what Owusu \& Larson (2014) found out in Ghana where majority of the Polytechnic students considered reading a boring activity. With high and positive perception of reading, one can conclude that the students are likely to have developed good reading habits.

Table $2 \mathrm{~b}$, on the other hand, presents the opinion of the respondents in the higher level of studies, 300 - 500 Level students. This group of students represents $20 \%$ of the total population that answered the items on perception.

Table 2b. Perception of Reading - Respondents in the $300-500$ Level

\begin{tabular}{lllll}
\hline Variable & Strongly Agree & Agree & Disagree & Strongly Disagree \\
\hline Reading is interesting & 48.57 & 47.62 & 16.67 & 19.23 \\
Reading is boring & 31.43 & 19.05 & 45.83 & 38.46 \\
I find reading very difficult & 20 & 33.33 & 37.50 & 42.31 \\
& 100 & 100 & 100 & 100 \\
\hline
\end{tabular}

The analysis revealed that this group has a negative perception about reading $(61.77 \%)$ while only $43.97 \%$ has a positive one. Can this be attributed to their seriousness? One can safely conclude that this is not a pleasant development because one would expect students at this level to be more studious and more endearing to reading.

3.2 Research Question 2: What Are the Factors/Reasons for the Decline in Reading Among Undergraduates?

The respondents affirmed that there was a decline in reading with $58 \%$ of them believing that undergraduates of today do not engage in serious reading. Figure 2 presents the picture. 


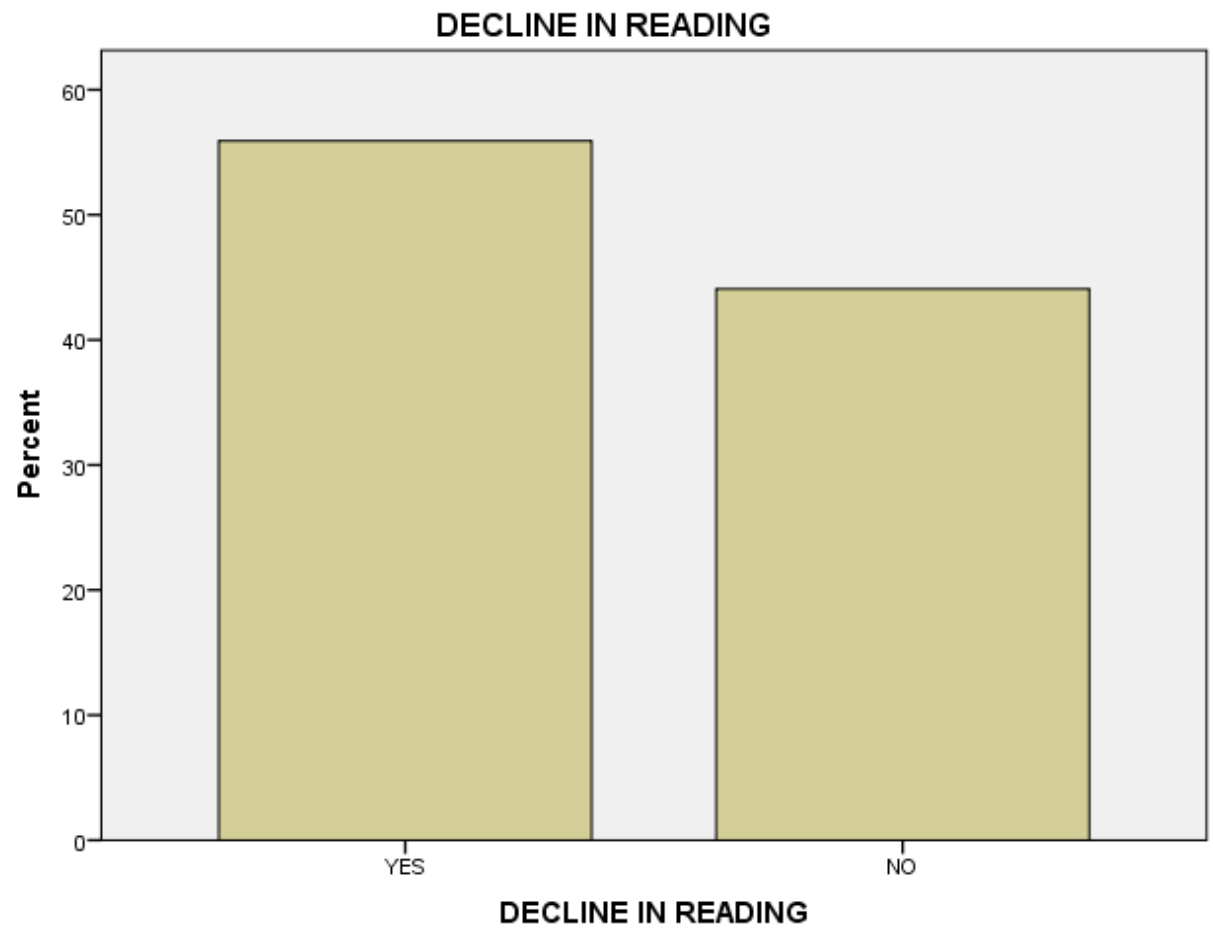

Figure 2. Decline in Reading among Undergraduates

Various reasons were adduced for the decline in reading. Table 3 presents the result. Please note that the results presented in this table were opinions of those respondents who believed that there was a decline in reading.

Table 3: Reasons for decline in reading

\begin{tabular}{llllll}
\hline & Frequency & Percent & Valid Percent & Cumulative Percent \\
\hline LACK OF PATIENCE & 20 & 10.1 & 17.4 & 17.4 \\
LACK OF INTEREST & 70 & 35.4 & 60.9 & 78.3 \\
SCHOOL ASSIGNMENTS & 5 & 2.5 & 4.3 & 82.6 \\
$\quad$ EASY AVAILABILITY OF & 5 & 2.5 & 4.3 & 87.0 \\
Valid & SUBSTITUTES(e-books) & & & & 94.8 \\
& ADVENT OF TV & 9 & 4.5 & 7.8 & 98.3 \\
& LACK OF ACCESS TO BOOKS & 4 & 2.0 & 3.5 & 100.0 \\
& OTHERS(if any) & 2 & 1.0 & 1.7 & \\
Total & 115 & 58.1 & 100.0 & \\
MissingSystem & 83 & 41.9 & & \\
Total & 198 & 100.0 & & \\
\end{tabular}




\section{Macrothink}

The study revealed that undergraduates of today lack interest in reading $(60.9 \%)$ and are equally not patient enough to want to engage in reading $(17.4 \%)$. These two factors had the highest percentage of 78.3. This has a serious implication on academic performance in that if a student lacks interest in reading, how would he / she engage in serious studying? This means that he would only be ready to read for examination purposes. It can also be deduced that the advent of the television as well as access to e-books (online reading) have made students lose interest in reading physical textbooks. Today, many students have snapshots of their notes on their smart phones. To them, the phone is more handy that the notebooks or textbooks. Unfortunately, this has not enhanced their reading motives/interests. If anything, it has somewhat aided examination malpractice as many students have been tempted to go into examinational hall with their phones. Some of the respondents believed that lack of access to books have reduced their interest in reading. Figure 3 showed that only $42 \%$ of the respondents endeavour to buy books while $38 \%$ would not mind borrowing from friends or the library. The study established that $21 \%$ of them read online.

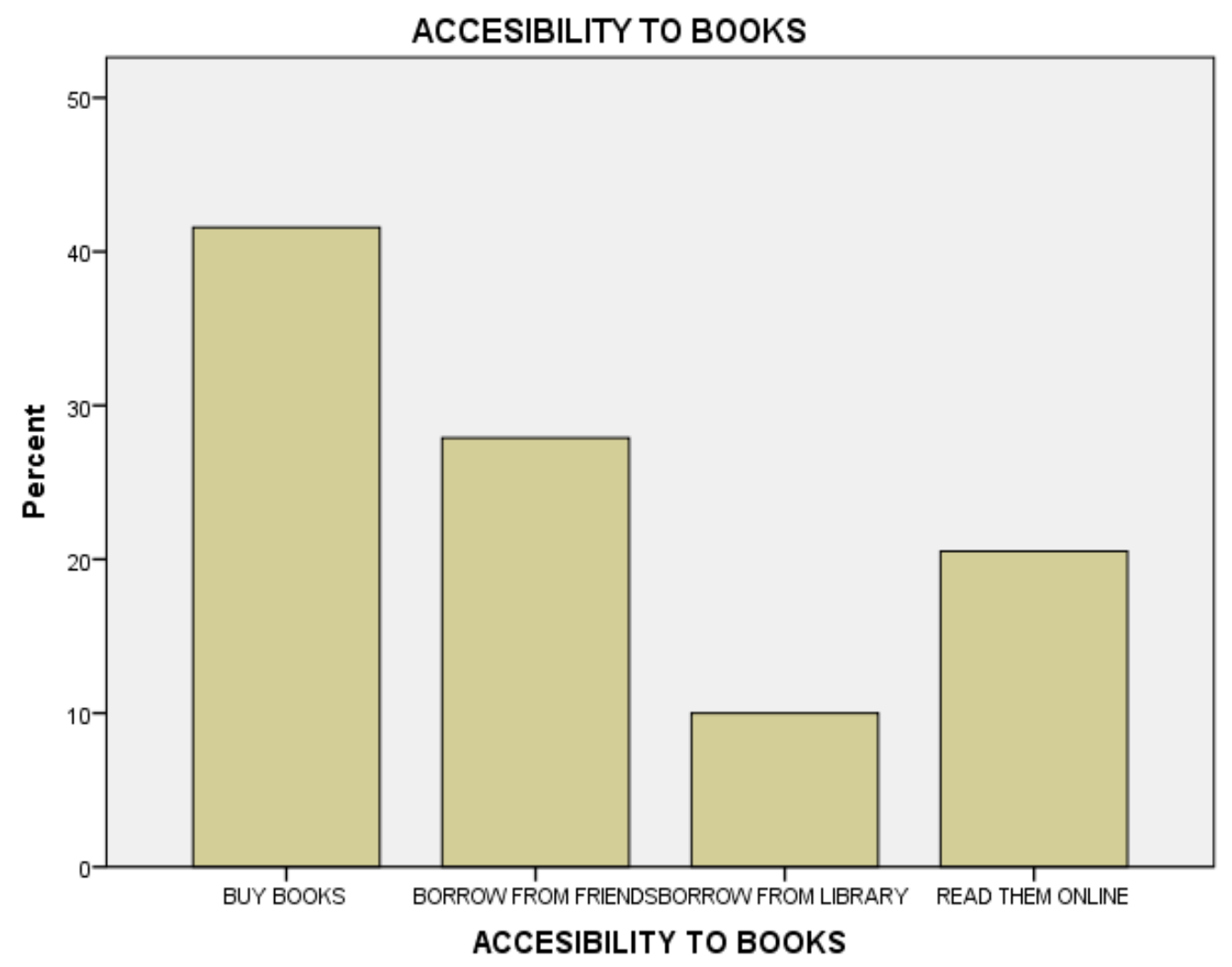

Figure 3. Accessibility to Books

\subsection{Research Question 3: How Can the Decline in Reading Be Stopped?}

In an attempt to stop the decline in reading, some suggestions were proffered to the respondents. All the suggestions were found to be plausible. The suggestions include making 
reading a compulsory component of the curriculum, encouragement from family and friends, and establishing reading clubs in the school/society.

Table 4. Suggested ways in improving reading

\begin{tabular}{|c|c|c|c|c|}
\hline ITEM & Frequency & Percent & $\begin{array}{l}\text { Valid } \\
\text { Percent }\end{array}$ & $\begin{array}{l}\text { Cumulative } \\
\text { Percent }\end{array}$ \\
\hline $\begin{array}{l}\text { Make reading compulsory in academic } \\
\text { curriculum }\end{array}$ & 60 & 30.3 & 33.3 & 33.3 \\
\hline Encouragement by family and friends & 80 & 40.4 & 44.4 & 77.7 \\
\hline Establishment of reading clubs & 40 & 20.2 & 22.2 & 99.9 \\
\hline Total & 180 & 90.9 & 99.9 & \\
\hline Missing Cases & 18 & 9.1 & 0.1 & \\
\hline Total & 198 & 100 & & \\
\hline
\end{tabular}

From the table above, encouragement by family and friends has the highest percentage of 44.4. This implies that families and friends have effect in what students read. Families that read to their children will no doubt encourage then to develop interest in reading. Equally, children that are exposed to reading novels, fiction, etc. from early years are likely to develop good reading habits. The next option that received high percentage $(33.3 \%)$ was making reading a compulsory component of the academic curriculum. For undergraduates to rate this option high means they acknowledge the need to engage in reading. Though reading comprehension is a component of the English Language curriculum at the secondary school level, language teachers have not really taken this aspect very seriously. This might be as a result of not having the competence to teach reading effectively and efficiently. If reading is not given priority in English language teaching/classroom, the situation in other subjects is better imagined than described. This suggestion is in line what with Obah (2008) suggested during the Silver Jubilee Celebrations of the Reading Association of Nigeria (RAN). She suggested making reading a "pervasive part of the academic climate".

Establishing reading clubs seems to have the least percentage - 22.2. One can infer that this means may not be a familiar option in our society. Though seemingly low in counts, reading habit/pattern is likely to improve when students have places where they can visit only to read. These clubs will, no doubt, afford students the opportunity to have variety of books to choose from. However, the rates to be charged should be minimal to encourage high patronage. The reading club should not however be limited to students. This will expose the students to some other people who can be mentors to them. Obah (2008) recommended setting up of reading centres and clinics where help on an individual basis would be provided. At the centres/clinics/clubs, activities such as story telling, poetry reading, book reviews, etc. can be encouraged. 


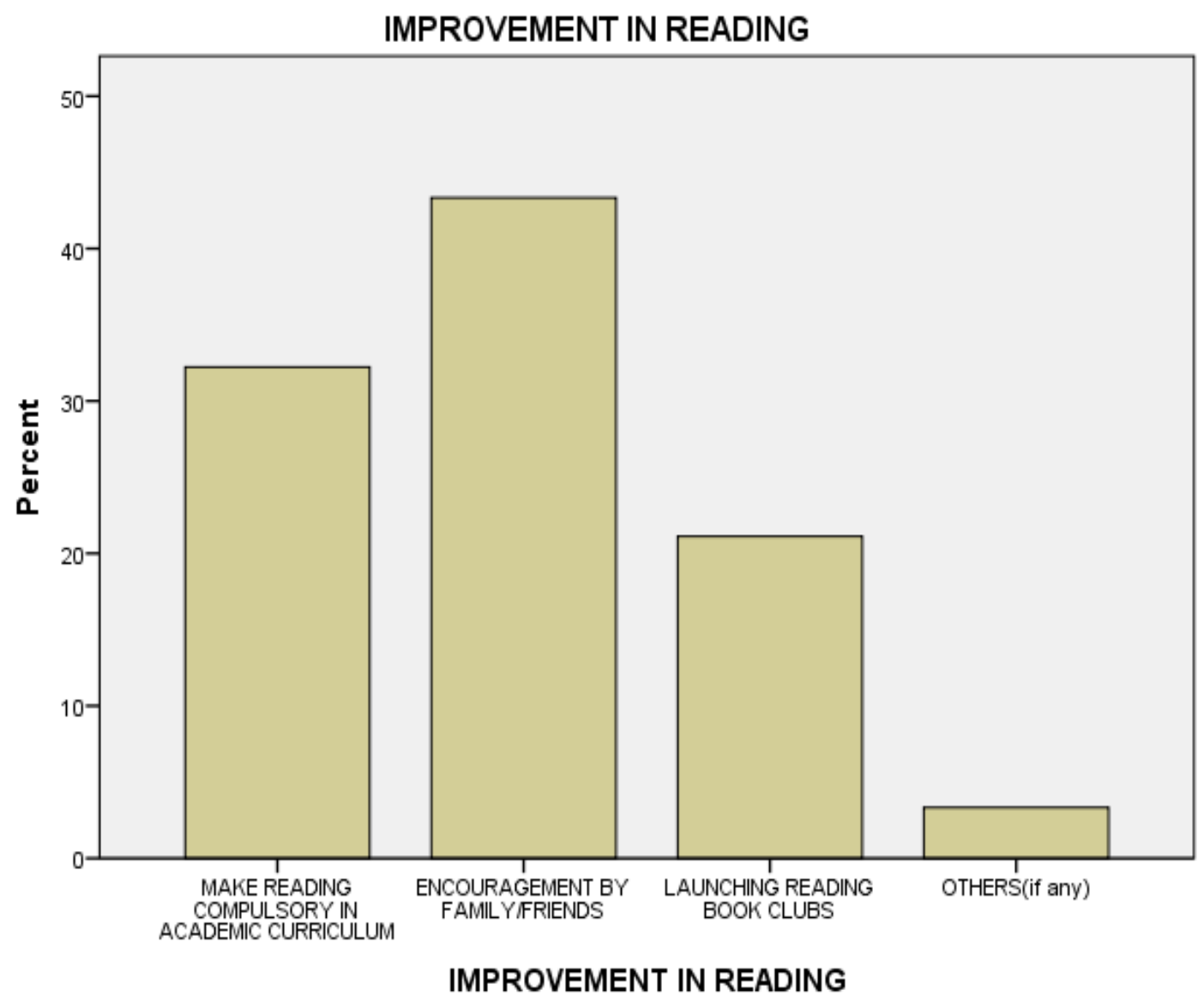

Figure 4. Suggested means in improving reading among undergraduates

3.4 Research Question 4: Is There a Relationship Between Reading (Habit) and Academic Performance of Undergraduates?

Table 5 presents the respondents' opinions about their reading habit. Many of the respondents (76.6\%) were of the opinion that the reading habit of undergraduates is very good. This is a good indication or implication for successful academic performance. 
Table 5. Opinion about Reading Habit

\begin{tabular}{llllll}
\hline & & Frequency & Percent & Valid Percent & Cumulative Percent \\
\hline \multirow{4}{*}{ Valid } & POOR & 54 & 27.3 & 28.4 & 28.4 \\
& GOOD & 106 & 53.5 & 55.8 & 84.2 \\
& EXCELLENT & 30 & 15.2 & 15.8 & 100.0 \\
\multirow{2}{*}{ Missing } & Total & 190 & 96.0 & 100.0 & \\
Total & System & 8 & 4.0 & & \\
\hline
\end{tabular}

Table 6. Reasons for reading

\begin{tabular}{|c|c|c|c|c|c|}
\hline & & Frequency & Percent & Valid Percent & Cumulative Percent \\
\hline \multirow{6}{*}{ Valid } & TO PASS THE EXAM & 44 & 22.2 & 22.6 & 22.6 \\
\hline & FOR FUN & 18 & 9.1 & 9.2 & 31.8 \\
\hline & TO BE WELL INFORMED & 67 & 33.8 & 34.4 & 66.2 \\
\hline & TO BE WELL DEVELOPED & 64 & 32.3 & 32.8 & 99.0 \\
\hline & TO WHILE AWAY TIME & 2 & 1.0 & 1.0 & 100.0 \\
\hline & Total & 195 & 98.5 & 100.0 & \\
\hline Missing & System & 3 & 1.5 & & \\
\hline Total & & 198 & 100.0 & & \\
\hline
\end{tabular}

Table 6 is a table showing reasons for reading. The variables presented in this table can be grouped under two categories - serious/active reading and pleasure reading. The variables under the serious reading such as reading to pass examination, to be well-developed and to be well-informed had very high percentages of $44 \%, 64 \%$ and $67 \%$ respectively. The pleasure reading variables: reading for fun and whiling away the time - received very low counts. The respondents are therefore aware of the fact that reading plays a very important role in their future. This position is corroborated by responses when asked if reading is in any way related to their academic performance. The responses are presented in percentages in Table 7. 


\section{Macrothink}

Table 7. Relationship between reading and academic performance

\begin{tabular}{lll}
\hline Variable & $\mathbf{A ~ \%}$ & D \% \\
\hline Does reading have any effect on your performance as student & 95.2 & 4.8 \\
$\begin{array}{l}\text { I prefer reading my textbook to any other book } \\
\text { My love for reading has helped me in my academics }\end{array}$ & 64 & 36 \\
I don't like reading out of my area of studies & 95.6 & 4.4 \\
Reading helps in shaping personality & 48.4 & 51.6 \\
Reading is a very important skill that has to be acquired early in life. & 90.1 & 9.9 \\
I read only when there is examination & 92.1 & 7.9 \\
\hline
\end{tabular}

From all the variables, there is a strong indication that reading has a positive effect and relationship with academic performance/achievement. $65.2 \%$ of the respondents disagreed with the fact that they read only when there is examination just as $51.6 \%$ of them would want to read out of their area of studies. It is very interesting to note that majority of the respondents $(90.1 \%)$ believed that reading helps in shaping their personality. This is a very good implication for character building as what they read is expected to mould their ways of life in the future. This finding is in consonance with Owusu-Acheaw and Larson (2014) who recorded a positive influence of reading habits on academic performance of polytechnic students in Ghana. Issa, et al (2012) equally found that continuous reading considerably influences studying skills and invariably academic performance.

Figure 5 below shows the overall picture of all the responses. From the pie-chart, it is evident that very few of the respondents $(13.6 \%)$ do not see reading as being related to academic performance while a large chunk of them $(86.5 \%)$ believed that academic performance can be influenced by reading. 


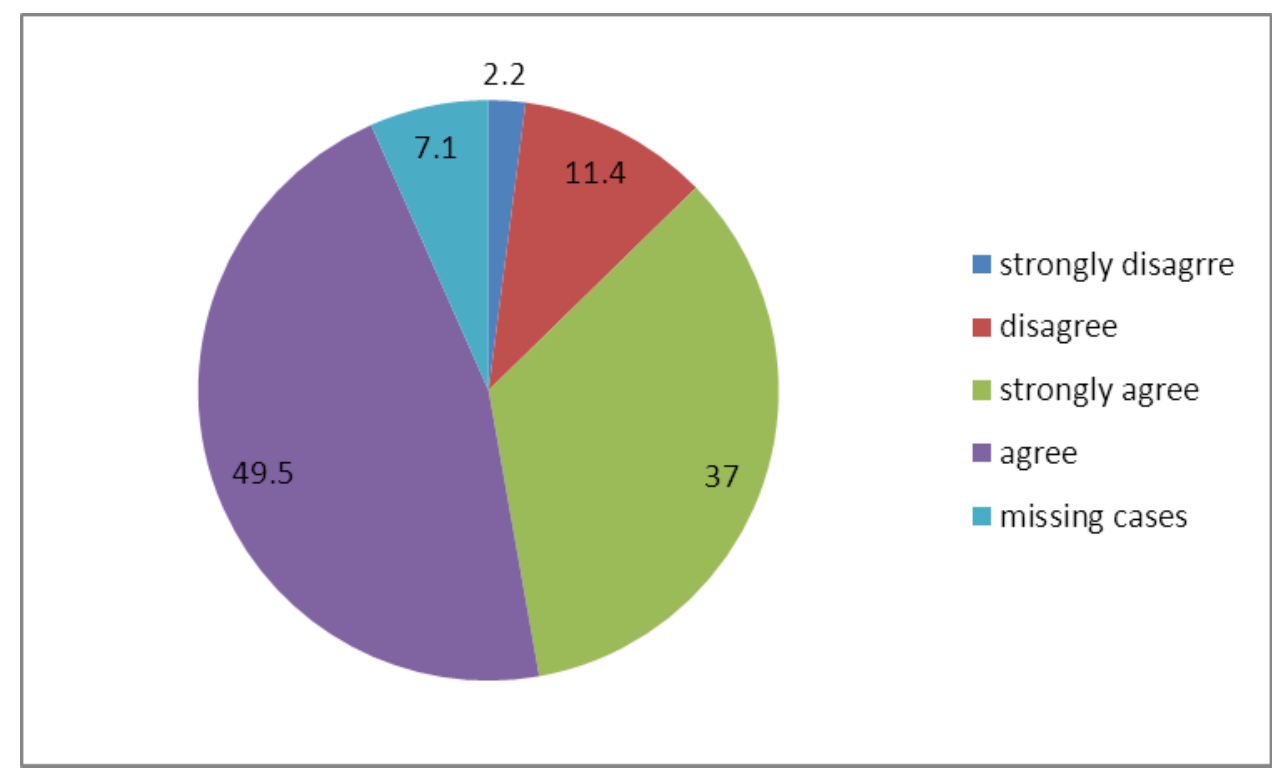

Figure 5. Relationship between reading and academic performance

\section{Conclusion}

The study has revealed that undergraduates have positive perception about reading. They equally believe that reading has a positive relationship /effect on their academic performance. This is why they would want reading embedded in their curriculum. The study has somewhat negated the opinion of some people that undergraduates do not engage in serious reading. Though some would prefer reading online, the fact remains that they still engage in reading. Engaging in reading for an average of two hours per day is good implication for academics when one considers that these students (especially those in private universities) have to attend to some compulsory activities on the campus. The supposed decline reading can be eradicated if family and friends encourage students in reading. Establishing reading centres/clubs/clinics has been identified as a means to curbing the decline. As Aina, et al (2011) proffered, mobile libraries can be provided as done in the 1970s.

\section{Recommendations}

From all indications, though some of the respondents believed that a decline in reading exists; facts have revealed that the students are serious about reading. Therefore, the paper recommends that reading as a subject should be inculcated in the university curriculum. The General Studies Unit should find a way of handling this as a core course. This is likely to enforce reading among undergraduates. This should be done in such a way that specific books are recommended for different levels especially 100 - 300 Level students. Teachers need to be equipped with the necessary training to be able to teach reading effectively, especially at the secondary school level. Establishing reading centres/clubs/clinics in higher institutions. These centres can also be provided in the town. These centres will go a long way in diagnosing the students' problems. Parents should give books as gifts to their children on special occasions such as on birthdays, during matriculation and even upon graduation. This 


\section{Macrothink}

International Journal of Learning and Development

ISSN 2164-4063 2018, Vol. 8, No. 2

will surely enable students to attach value not only to reading but to books generally. Finally, parents should serve as role models by reading at home and sharing interesting write-ups with their wards. Reading skill and interest in reading are likely to be instilled into the students from home. Teachers would only need to improve upon these skills and interest.

\section{References}

Adegbile, S. O. (2002). Advance Organizers and the Secondary School Teacher. Teaching Strategies for Nigerian secondary schools. Ibadan: Powerhouse Press and Publishers.

Aina, J. A., Ogungbemi, J. I., \& Adigun, J. A. (2011). Poor reading habits among Nigerians: The role of Libraries in Library Philosophy and Practice. Retreived from http://unlib.unl.edu/LPP

Antwi, I. K. (1985). The reading habits and interest of secondary schools students in Bauchi Metropolis: A Case Study. Lagos: Nigerian Libraries, 2(2), 52-53.

Bashir, I., \& Mattoo, N. H. (2012) A study of Study Habits and Academic Performance among Adolescents (14 -19) years. International Journal of Social Science Tomorrow, 1(5), $1-5$.

Isiugo-Abanihe, I. M. (1991). Content Area reading instructional strategies and JSS Students' Comprehension and retention of science texts. Ph.D Thesis. University of Ibadan.

Obah, T. Y. (2008). Celebrations Time is Here-But it is not yet Uhuru: Some Challenges Ahead. A Keynote Address at the $11^{\text {th }}$ Biennial Conference and Silver Jubilee Celebration of the Reading Association of Nigeria (RAN) on October 8, 2008.

Owusu-Acheaw, M., \& Larson, A. G. (2014). Reading Habits among students and its effect on academic performance: A Study of Students of Koforidua Polytechnic. Library Philosophy and Practice (e-journal), Libraries at University of Nebraska-Lincoln 6-5-2014.

Palani, K. K. (2012). Promising Reading Habits and Creating Literate Social. International Reference Research Journal, 3, 2(1), 91.

Rubin, D. (2002). Diagnosis and correction in reading and guiding reading instructions (4th ed.). Boston. Allym \& Bacon.

\section{Copyright Disclaimer}

Copyright for this article is retained by the author(s), with first publication rights granted to the journal.

This is an open-access article distributed under the terms and conditions of the Creative Commons Attribution license (http://creativecommons.org/licenses/by/4.0/). 